\title{
Språklig slurv fra Oslo universitetssykehus
}

\author{
Er det urimelig å forvente at avdelingsnavn er riktig skrevet i brevhoder og stillingsannonser fra landets \\ største universitetssykehus?
}

Oslo universitetssykehus består av de tidligere sykehusene Rikshospitalet, Radiumhospitalet, Ullevål sykehus og Aker sykehus. Sykehusfusjonen i 2009 innebar en full gjennomgang av organisasjonsstrukturen og opprettelse av helt nye klinikker og avdelinger.

En av avdelingene i Klinikk for kirurgi og nevrofag er Avdeling for plastikk- og rekonstruktiv kirurgi. Dette navnet viser hva avdelingen driver med: plastikkirurgi og rekonstruktiv kirurgi. Tilsvarende avdelinger på det tidligere Rikshospitalet og Ullevål universitetssykehus het begge Plastikkirurgisk avdeling, selv om skrivemåten Plastisk kirurgisk avdeling også ble brukt.

Den nye avdelingen benyttet altså anledningen til å presisere at fagområdet plastikkirurgi også omfatter rekonstruktiv kirurgi, dvs. rekonstruktiv kirurgi ved bl.a. medfødte misdannelser, kreftkirurgi og skader. Det nye navnet er nokså langt og dermed mindre anvendelig, men er dekkende for virksomheten og korrekt skrevet på sykehusets nettsider (1). Skrivemåten Avdeling for plastisk og rekonstruktiv kirurgi burde kanskje vært foretrukket, så slapp man den litt uheldige delingen av ordet plastikkirurgi. Mye tyder på at et så langt navn vil bli lite brukt i det daglige, og at mange vil ha vansker med å skrive det korrekt.

I et hefte som sykehuset har utgitt for å gi en oversikt over alle organisasjons- og navneendringene (2), er navnet skrevet slik:

Avdeling for plastikk og rekonstruktiv kirurgi

I de faste brevhodene på brevark som brukes for epikriser til henvisende leger og annen korrespondanse, er avdelingsnavnet skrevet på (minst) tre ulike måter, to av dem på ett og samme ark:

Avd for plastikk og rek. kir Avd. for plastikk og rekonstr. kir. Avd. plastikk og rekons. kir.

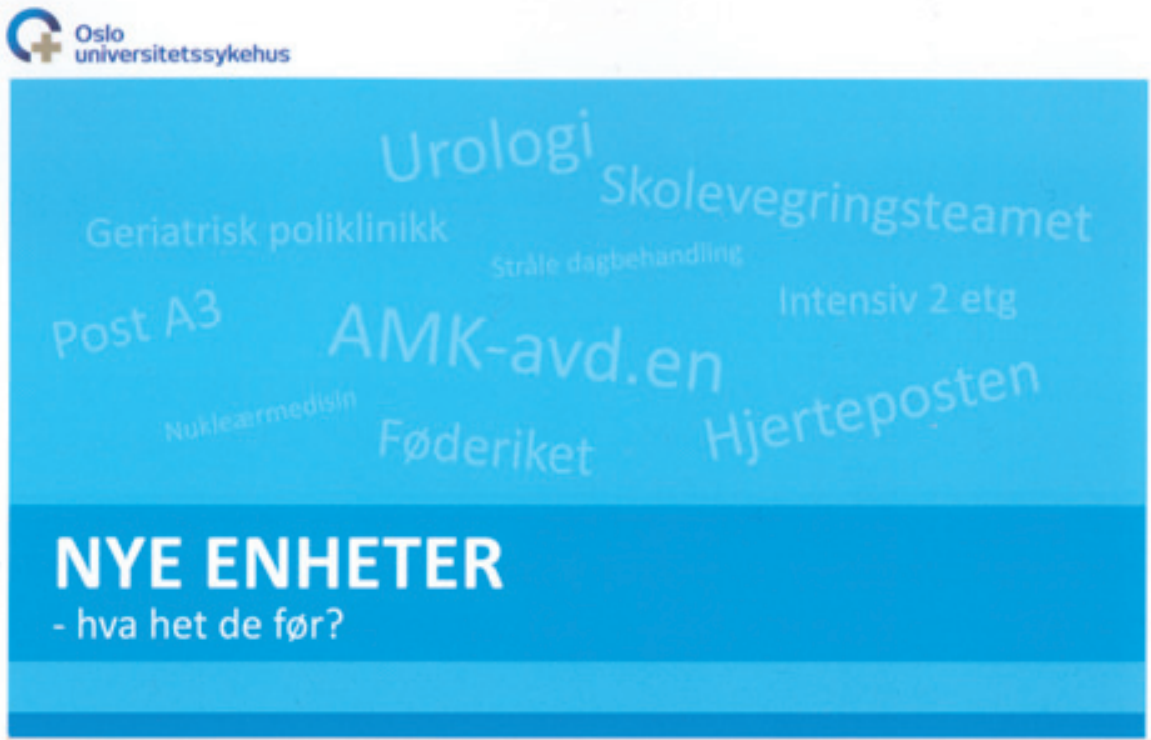

En oversikt over nye enheter i Oslo universitetssykehus og hva de het for

Dette heftet på til sammen 125 sider er utgitt for å gi en oversikt over nye og gamle navn på enheter ved Oslo universitetssykehus (2)
Her mangler bindestrek etter plastikk, punktum etter forkortelser og/eller ordet for. Det er nokså uvanlig å bruke forkortelser som rek., rekonstr. og rekons., i hvert fall i en slik offisiell sammenheng.

I en stillingsannonse i Tidsskriftet nr. 19/2010 med overskriften Ledig professorat/overlege i medisin til plastikk og rekonstruktiv kirurgi (sic!) er avdelingsnavnet skrevet slik (3):

\section{KKN AVD FOR PLASTIKK OG REKONSTRUKTIV KIRURGI}

Fortsatt uten bindestrek etter plastikk og uten punktum etter forkortelsen for avdeling, men nå med bokstavene KKN aller først - hva KKN står for, er ikke umiddelbart forståelig. Resten av annonseteksten inneholder mange skrivefeil. Er det ingen på sykehuset som kontrolleser slike annonsetekster?

Skriftnormer etterleves ikke i samme grad som tidligere - mange skriver sjokolade kake om sjokoladekake og lamme kjøtt om lammekjøtt. Så kanskje er dette en kamp mot vindmøller. Men fra en vitenskapelig institusjon på dette akademiske nivået bør man kunne forvente mer. Tre eksempler på slurv ved én og samme avdeling med systematisk feilskriving av avdelingens navn gir et dårlig inntrykk. Og det i en spesialitet som er kjent for nøyaktighet, korrekte kirurgiske snitt og pene operasjonsarr.

\section{Petter Gjersvik \\ petjense@online.no \\ Observatorie terrasse 7C \\ 0270 Oslo}

Oppgitte interessekonflikter: Forfatteren er førsteamanuensis ved Oslo universitetssykehus, Rikshospitalet, og medisinsk redaktør i Tidsskriftet.

Litteratur

1. Oslo universitetssykehus. Avdelinger www.oslo-universitetssykehus.no/OMOSS/ AVDELINGER/Sider/side.aspx (5.10.2010).

2. Nye enheter - hva het de før? Oslo: Oslo universitetssykehus, 2010.

3. Oslo universitetssykehus. Ledig professorat/overlege i medisin til plastikk og rekonstruktiv kirurgi. Stillingsannonse. Tidsskr Nor Legeforen 2010; 130: 1978. 